\title{
QUALITY OF LIFE ASSESSMENT IN VITILIGO PATIENTS IN LITHUANIA
}

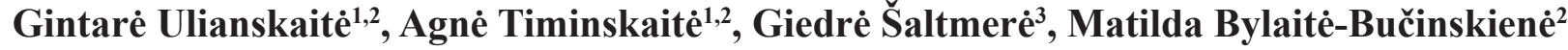 \\ ${ }^{I}$ Centre of Dermatovenereology, Vilnius University Hospital Santaros Clinics, Vilnius, Lithuania, \\ ${ }^{2}$ Vilnius University Faculty of Medicine, Vilnius, Lithuania, \\ ${ }^{3}$ Innovative Dermatology Center, Vilnius, Lithuania
}

Keywords: DLQI, Quality of Life, Vitiligo, VitiQoL.

\begin{abstract}
Summary
Vitiligo is a chronic autoimmune skin disorder that results as depigmented patches of the skin due to loss of melanocytes. Although the disease is often asymptomatic, it impairs patients' quality of life. The aim of this study was to assess factors associated with negative impact on quality of life in terms of disease clinical features, patients` functioning and emotional status in Lithuania. An observational, cross-sectional study consisted of 131 respondents. An original three-part survey of 41-questions was developed based on 4 standardized questionnaires. 125 respondents were included: 94 women and 31 men. The mean age was $35 \pm 12$ years. 14 out of 21 quality of life items affect $>25 \%$ of respondents, including all 10 emotion-related indicators $(100 \%)$ and 4 out of 11 functioning-related indicators (36.36\%). In conclusion, this research supports the evidence that vitiligo has an influence on patients' quality of life, mainly affecting emotion-related areas. Quality of life is associated with gender, age, and extent of skin involvement. Psychological consultation should be recommended to patients with vitiligo.
\end{abstract}

\section{Introduction}

Vitiligo is an acquired chronic autoimmune skin disorder that results as white depigmented patches of the skin due to loss of functioning melanocytes. The prevalence of the disease varies based on region, usually affecting 0.5$2.0 \%$ of the population worldwide [1]. Vitiligo affects men and women equally and may appear at any age, however, in over a half of individuals vitiligo occurs before the age of 20 years [2]. The disease is classified into two major groups: non-segmental vitiligo, which is more common and the lesions are symmetrical, and segmental vitiligo, which occurs unilaterally and may fully or partially correspond to the course of the dermatome [3]. Although vitiligo is often asymptomatic, it undoubtedly impairs patients' quality of life (QoL). Nevertheless, individuals often confront some difficulties getting the right vitiligo treatment since vitiligo is often considered as a "cosmetic" issue [4]. This condition can be stigmatizing and psychologically devastating. It causes stress, anxiety, low self-esteem, social isolation and leads to patients' decreased psychological well-being. It is important to mention that the majority affected by vitiligo are worried about the possible progression of the disease $[1,4]$. Although there is no epidemiological data about vitiligo in Lithuania, we observe that more patients seek consultations for the latest treatment options of vitiligo. It is highly recommended to assess QoL in people with vitiligo and follow it during the course of treatment and disease [1]. The most used questionnaires include multipurpose and frequently used Dermatology Life Quality Index (DLQI), Skindex-16 and disease-specific Vitiligo Quality of Life (VitiQoL) index.

In summary, a number of studies have already shown that vitiligo has a high impact on individuals' QoL and mental health [4-6]. It also depends on demographic characteristics, such as gender, age, disease duration, disease affected area, etc. We conducted a three-part survey to evaluate factors associated with negative impact on QoL in terms of disease clinical features, patients' functioning and emotional status. This is the first study to assess QoL in Lithuanian patients with vitiligo.

The aim. The aim of this study was to assess factors associated with negative impact on QoL in terms of disease clinical features, patients` functioning and emotional status in Lithuania.

\section{Material and methods}

An observational, cross-sectional study was conducted in Lithuania. The study was approved by the Joint Centre for 
Competences and Biomedical Studies of Vilnius University Hospital Santaros Clinics on 4 of April 2019 (No. SR-1199). This study was based on a survey method. Self-reported anonymous questionnaire on QoL with vitiligo was carried out between April 4 to December 31, 2019. The data was collected in the Centre of Dermatovenereology at Vilnius University Hospital Santaros klinikos, Innovative Dermatology Center and via vitiligo online social communities.

The inclusion criteria for the study were people with vitiligo over the age of 16 years old. A total of 131 respondents fully completed the questionnaire, 125 of them were included in the data analysis. Based on standardized DLQI, Skindex-16 and VitiQoL, Self-Assessment Vitiligo Extent Score (SA-VES) questionnaires, an original three-part survey of 41 questions was developed. The first part consisted of questions concerning demographics, manifestation, clinical features, treatment of vitiligo, comorbidities, and sunbathing habits; second part - visual involvement of the skin; third part - QoL assessment by emotional and functional areas.

The statistical analysis was performed using Microsoft Excel $^{\circledR}$ and Statistical Package for Social Sciences (IBM SPSS $^{\circledR}$ v.25.0). Qualitative and quantitative analysis, including descriptive statistics, were used to describe the data. Quantitative variables were described using the mean value \pm standard deviation, qualitative variables - using counts and percentages. Qualitative data analysis was performed using Pearson chi square $\left(\chi^{2}\right)$ test, while quantitative analysis - Kruskal-Wallis test. Pearson correlation coefficient was used to perform analysis of correlation. A $p$ value $<0.05$ was considered statistically significant.

Table 1. Demographic data of the respondents.

\begin{tabular}{|l|c|c|}
\hline \multirow{2}{*}{ Age } & \multicolumn{2}{|c|}{ Mean \pm SD, years } \\
\hline \multirow{4}{*}{ Gender } & No. of respondents $(\%)$ \\
\hline \multirow{4}{*}{ Education } & Female & $94(75,2)$ \\
\cline { 2 - 3 } & Male & $31(24,8)$ \\
\cline { 2 - 3 } & Current university education & $22(17,6)$ \\
\cline { 2 - 3 } & Grade 12 & $17(13,6)$ \\
\cline { 2 - 3 } & Grade 1-10 & $8(6,4)$ \\
\hline \multirow{4}{*}{$\begin{array}{l}\text { Residential } \\
\text { location }\end{array}$} & Capital (Vilnius) & $68(54,4)$ \\
\cline { 2 - 3 } & Kaunas & $13(10,4)$ \\
\cline { 2 - 3 } & Klaipeda & $6(4,8)$ \\
\cline { 2 - 3 } & Siauliai & $4(3,2)$ \\
\cline { 2 - 3 } & Panevezys & $30(24)$ \\
\hline
\end{tabular}

\section{Results}

A total of 125 respondents were included in the study: $94(75.2 \%)$ women and $31(248 \%)$ men. The mean age was $35 \pm 12$ years. Most of the respondents $(n=78 ; 62.4 \%)$ have

Table 2. Clinical data of the vitiligo study respondents.

\begin{tabular}{|c|c|c|}
\hline & \multicolumn{2}{|c|}{ Mean $\pm \mathrm{SD}$, years } \\
\hline \multirow[t]{2}{*}{ Age of onset } & \multicolumn{2}{|c|}{$21 \pm 12$} \\
\hline & \multicolumn{2}{|c|}{ No. of respondents (\%) } \\
\hline \multirow{5}{*}{$\begin{array}{l}\text { Location of vitiligo } \\
\text { primary manifestation }\end{array}$} & Head & $40(32)$ \\
\hline & Trunk & $32(25,6)$ \\
\hline & Genital area & $30(24)$ \\
\hline & Upper extremities & $58(46,4)$ \\
\hline & Lower extremities & $21(16,8)$ \\
\hline \multirow{2}{*}{$\begin{array}{l}\text { Stressful event prior to } \\
\text { disease manifestation }\end{array}$} & Yes & $73(58,4)$ \\
\hline & No & $52(41,6)$ \\
\hline \multirow{4}{*}{$\begin{array}{l}\text { Season at onset of } \\
\text { vitiligo }\end{array}$} & Summer & $68(54,4)$ \\
\hline & Spring & $34(27,7)$ \\
\hline & Autumn & $9(7,2)$ \\
\hline & Winter & $14(11,2)$ \\
\hline \multirow{2}{*}{$\begin{array}{l}\text { Family history of } \\
\text { vitiligo }\end{array}$} & Yes & $90(72)$ \\
\hline & No & $35(28)$ \\
\hline \multirow{2}{*}{ Involvement } & Bilateral & $89(71,2)$ \\
\hline & Unilateral & $36(28,8)$ \\
\hline \multirow{5}{*}{$\begin{array}{l}\text { Body surface affected } \\
\text { by vitiligo }\end{array}$} & $1-25 \%$ & $89(71,2)$ \\
\hline & $26-50 \%$ & $25(20)$ \\
\hline & $51-75 \%$ & $5(4)$ \\
\hline & $76-99 \%$ & $4(3,2)$ \\
\hline & $100 \%$ & $2(1,6)$ \\
\hline $\begin{array}{l}\text { Mean of body surface } \\
\text { affected (assessed using } \\
\text { SA-VES), } \%\end{array}$ & & 7,82 \\
\hline \multirow{3}{*}{$\begin{array}{l}\text { Disease progression } \\
\text { during past } 3 \text { months }\end{array}$} & No change & $57(45,6)$ \\
\hline & Improving & $14(11,2)$ \\
\hline & Progressing & $54(43,2)$ \\
\hline \multirow{2}{*}{ Treatment received } & Yes & $70(56)$ \\
\hline & No & $55(44)$ \\
\hline \multirow{6}{*}{ Comorbidities } & $\begin{array}{c}\text { Autoimmune } \\
\text { thyroiditis }\end{array}$ & $17(13,6)$ \\
\hline & Psoriasis & $8(6,4)$ \\
\hline & Urticaria & $2(1,6)$ \\
\hline & Lichen planus & $1(0,8)$ \\
\hline & Rheumatoid arthritis & $1(0,8)$ \\
\hline & $\begin{array}{c}\text { Diabetes mellitus } \\
\text { (type I) }\end{array}$ & $1(0,8)$ \\
\hline \multirow{2}{*}{$\begin{array}{l}\text { Sunbathing during } \\
\text { vacation/summer }\end{array}$} & Yes & $81(64,8)$ \\
\hline & No & $44(35,3)$ \\
\hline \multirow{2}{*}{ Sun protection } & Yes & $112(89,6)$ \\
\hline & No & $13(10,4)$ \\
\hline
\end{tabular}


Table 3. Indicators of quality of life by vitiligo affected number of respondents.

\begin{tabular}{|c|c|c|}
\hline $\begin{array}{l}\text { Indicators (In the order of } \\
\text { frequency) }\end{array}$ & $\begin{array}{c}\text { No of affected } \\
\text { patients }(\%)\end{array}$ & Domain \\
\hline $\begin{array}{l}\text { Worrying about progression of } \\
\text { disease }\end{array}$ & $85(67,4 \%)$ & Emotion \\
\hline $\begin{array}{l}\text { Skin condition affected sun } \\
\text { protection efforts during recrea- } \\
\text { tion (i.e. limiting exposure time } \\
\text { during peak sun hours, seeking } \\
\text { shade, wearing hat, long sleeves } \\
\text { or pants) }\end{array}$ & $76(60,8 \%)$ & $\begin{array}{l}\text { Functio- } \\
\text { ning }\end{array}$ \\
\hline $\begin{array}{l}\text { Being bothered by the appea- } \\
\text { rance of their skin condition }\end{array}$ & $63(50,4 \%)$ & Emotion \\
\hline $\begin{array}{l}\text { Skin condition affected emotio- } \\
\text { nal well-being }\end{array}$ & $53(42,4 \%)$ & Emotion \\
\hline $\begin{array}{l}\text { Feeling frustration about their } \\
\text { skin condition }\end{array}$ & $52(41,6 \%)$ & Emotion \\
\hline $\begin{array}{l}\text { Being annoyed about their skin } \\
\text { condition }\end{array}$ & $51(40,8 \%)$ & Emotion \\
\hline $\begin{array}{l}\text { Skin influenced the clothes that } \\
\text { they wear }\end{array}$ & $50(40 \%)$ & $\begin{array}{l}\text { Functio- } \\
\text { ning }\end{array}$ \\
\hline $\begin{array}{l}\text { Feeling self-conscious because } \\
\text { of their skin }\end{array}$ & $47(37,6 \%)$ & Emotion \\
\hline $\begin{array}{l}\text { Feeling worried about what other } \\
\text { people may be thinking of them }\end{array}$ & $45(36 \%)$ & Emotion \\
\hline $\begin{array}{l}\text { Feeling embarrassed because of } \\
\text { the skin }\end{array}$ & $43(34,4 \%)$ & Emotion \\
\hline $\begin{array}{l}\text { Feeling depressed because of the } \\
\text { skin condition }\end{array}$ & $43(34,4 \%)$ & Emotion \\
\hline $\begin{array}{l}\text { Skin condition affected groo- } \\
\text { ming habits (i.e. hairstyle, use } \\
\text { of cosmetics) }\end{array}$ & $42(33,6 \%)$ & $\begin{array}{l}\text { Functio- } \\
\text { ning }\end{array}$ \\
\hline $\begin{array}{l}\text { Feeling afraid that people will } \\
\text { find fault with them }\end{array}$ & $41(32,8 \%)$ & Emotion \\
\hline $\begin{array}{l}\text { Skin condition affected social or } \\
\text { leisure activities }\end{array}$ & $35(28 \%)$ & $\begin{array}{c}\text { Functio- } \\
\text { ning }\end{array}$ \\
\hline $\begin{array}{l}\text { Skin condition affected overall } \\
\text { physical health }\end{array}$ & $26(20,8 \%)$ & $\begin{array}{l}\text { Functio- } \\
\text { ning }\end{array}$ \\
\hline $\begin{array}{l}\text { Skin condition made it hard to } \\
\text { show affection }\end{array}$ & $25(20 \%)$ & $\begin{array}{c}\text { Functio- } \\
\text { ning }\end{array}$ \\
\hline $\begin{array}{l}\text { Skin condition influenced their } \\
\text { desire to be with people }\end{array}$ & $24(19,2 \%)$ & $\begin{array}{l}\text { Functio- } \\
\text { ning }\end{array}$ \\
\hline $\begin{array}{l}\text { Skin condition made it hard to } \\
\text { work or do what they enjoy }\end{array}$ & $22(17,6 \%)$ & $\begin{array}{l}\text { Functio- } \\
\text { ning }\end{array}$ \\
\hline $\begin{array}{l}\text { Skin condition created problems } \\
\text { with a partner or any of close } \\
\text { friends or relatives }\end{array}$ & $21(16,8 \%)$ & $\begin{array}{l}\text { Functio- } \\
\text { ning }\end{array}$ \\
\hline $\begin{array}{l}\text { Skin condition affected the chan- } \\
\text { ces for making new friends }\end{array}$ & $18(14,4 \%)$ & $\begin{array}{l}\text { Functio- } \\
\text { ning }\end{array}$ \\
\hline $\begin{array}{l}\text { Skin condition prevented from } \\
\text { working or studying }\end{array}$ & $5(4 \%)$ & $\begin{array}{c}\text { Functio- } \\
\text { ning }\end{array}$ \\
\hline
\end{tabular}

acquired university education. Table 1 reveals other demographic characteristics of the respondents.

Mean age of vitiligo onset was $21 \pm 12$ years. In 87 $(69.6 \%)$ respondents the disease manifested in only 1 area, and the most common site of primary lesions was the upper extremities $(\mathrm{n}=58 ; 46.4 \%)$. More than a half of the respondents $(n=73 ; 58.4 \%)$ have experienced stress prior to manifestation of vitiligo. The majority have noticed the primary lesions of vitiligo in summer $(\mathrm{n}=68 ; 54.4 \%)$. Positive familial history of vitiligo was reported in $90(72 \%)$ respondents. In $89(71.2 \%)$ respondents the lesions were distributed bilaterally and covered $1-25 \%$ of body surface. On average, $7.82 \%$ of the total body surface was affected. Around a half of the patients $(n=70 ; 56 \%)$ have received vitiligo treatment, the most common treatment option being phototherapy $(\mathrm{n}=34$, $48.57 \%$ ). 20 (28.57\%) respondents received local treatment (calcineurin inhibitors, glucocorticosteroids or both) in com-

Table 4. Comparison of gender and indicators of quality of life in vitiligo patients.

\begin{tabular}{|c|c|c|c|c|}
\hline $\begin{array}{l}\text { Indicator of } \\
\text { quality of } \\
\text { life }\end{array}$ & Answer & $\begin{array}{c}\text { Women, } \\
\text { n (\%) }\end{array}$ & $\begin{array}{l}\text { Men, } \\
\text { n (\%) }\end{array}$ & $P$ value \\
\hline \multirow{3}{*}{$\begin{array}{l}\text { Feeling } \\
\text { embarrassed } \\
\text { because of } \\
\text { the skin }\end{array}$} & No & $60(63,8 \%)$ & $22(71,0 \%)$ & \multirow{3}{*}{0,00} \\
\hline & Moderate & $2(2,1 \%)$ & $6(19,3 \%)$ & \\
\hline & Yes & $32(34,1 \%)$ & $3(9,7 \%)$ & \\
\hline \multirow{3}{*}{$\begin{array}{l}\text { Being } \\
\text { annoyed } \\
\text { because of } \\
\text { your skin } \\
\text { condition }\end{array}$} & $\mathrm{No}$ & $52(55,3 \%)$ & $22(71 \%)$ & \multirow{3}{*}{0.004} \\
\hline & Moderate & $9(9,6 \%)$ & $7(22,6 \%)$ & \\
\hline & Yes & $33(35,1 \%)$ & $2(6,4 \%)$ & \\
\hline \multirow{3}{*}{$\begin{array}{l}\text { Skin influ- } \\
\text { enced the } \\
\text { clothes that } \\
\text { you wear }\end{array}$} & No & $50(53,2 \%)$ & $25(80,6 \%)$ & \multirow{3}{*}{0,005} \\
\hline & Moderate & $9(9,6 \%)$ & $4(12,9 \%)$ & \\
\hline & Yes & $35(37,2 \%)$ & $2(6,5 \%)$ & \\
\hline \multirow{3}{*}{$\begin{array}{l}\text { Feeling } \\
\text { depressed } \\
\text { because } \\
\text { of the skin } \\
\text { condition }\end{array}$} & No & $56(59,6 \%)$ & $26(83,9 \%)$ & \multirow[b]{3}{*}{0,037} \\
\hline & Moderate & $6(6,4 \%)$ & $0(0 \%)$ & \\
\hline & Yes & $32(34 \%)$ & $5(16,1 \%)$ & \\
\hline \multirow{3}{*}{$\begin{array}{l}\text { Worried } \\
\text { about } \\
\text { progression/ } \\
\text { spread of } \\
\text { disease }\end{array}$} & No & $28(29,8 \%)$ & $12(38,7 \%)$ & \multirow[b]{3}{*}{0,006} \\
\hline & Moderate & $9(9,6 \%)$ & $9(29 \%)$ & \\
\hline & Yes & $57(60,6 \%)$ & $10(32,3 \%)$ & \\
\hline $\begin{array}{l}\text { Skin condi- } \\
\text { tion affected } \\
\text { grooming } \\
\text { habits (i.e. } \\
\text { hairstyle, use } \\
\text { of cosmetics) }\end{array}$ & No & $58(61,7 \%)$ & $25(80,6 \%)$ & 0,022 \\
\hline
\end{tabular}


bination with phototherapy. The improvement of the disease was observed in only $14(11.2 \%)$ respondents, though the progression was reported by 54 (43.2) patients. In our sample, the most common comorbidity in patients with vitiligo was autoimmune thyroiditis $(n=17 ; 13.6 \%)$. Sunbathing habits were also assessed. The survey revealed that the majority of respondent's sunbathe $(\mathrm{n}=81 ; 64.8 \%)$ and use sun protection during recreation $(\mathrm{n}=112 ; 89.6)$. More detailed information is provided in Table 2.

Table 3 describes affected vitiligo patients by individual indicators of QoL questionnaire. 14 out of 21 QoL items have affected $>25 \%$ of respondents, including all 10 emotion-related indicators $(100 \%)$ and 4 out of 11 functioningrelated indicators $(36.36 \%)$. Worrying about progression of the disease has affected the most respondents $(n=85 ; 67.4 \%)$. Vitiligo has prevented only $5(4 \%)$ respondents from working or studying. Out of emotion-related items, worrying about progression of the disease has affected the vast majority $(n=85 ; 67.4 \%)$, while fear of other people finding fault with them has affected the lowest number of respondents $(n=41$; $32.8 \%$ ). Out of functioning-related domains, most respondents $(\mathrm{n}=76 ; 60.0 .8 \%)$ reported that vitiligo affected their sun protection efforts during holidays, while the least number of respondents $(n=5 ; 4 \%)$ reported that vitiligo prevented them from working or studying.

Some statistically significant differences in individual indicators of QoL questionnaire related to gender were observed (Table 4). In our study, women were more likely than men to be worried about the progression of vitiligo $(p=0.006)$, felt embarrassed $(p=0.000)$ and depressed $(p=0.037)$, were annoyed $(p=0.000)$ about their skin condition. Furthermore, vitiligo has influenced grooming practices $(p=0.022)$ and choice of clothes $(p=0.005)$ more in women than in men.

The linear dependence between age and indicators of QoL were observed. Older respondents tend to experience more emotional problems due to vitiligo. Older people compared to younger ones, were more likely to be bothered due to the appearance of their skin $(r=0.297 ; p=0.001)$, felt frustrated $(\mathrm{r}=0.284 ; \mathrm{p}=0.001)$, embarrassed $(\mathrm{r}=0.282 ; \mathrm{p}=0.002)$, felt worried about other people's opinion $(\mathrm{r}=0.282 ; \mathrm{p}=0.001)$ and about progression of the disease $(r=0.238 ; \mathrm{p}=0.008)$. Older respondents found it difficult to show affection due to their skin condition $(r=0.27 ; p=0.002)$.

The extent of skin involvement was associated with impaired QoL. Respondents with 25-50\% of the skin involved were more likely to be bothered $(\mathrm{p}=0.004)$ and embarrassed by the appearance of their skin $(\mathrm{p}=0.047)$ than respondents with a lower extent of skin involvement. Respondents, whose $25-50 \%$ of skin was involved, were associated with gre- ater impact on overall physical health $(\mathrm{p}=0.000)$, emotional well-being $(p=0.026)$, social or leisure activities $(p=0.000)$, the choice of clothes $(\mathrm{p}=0.00)$, desire to be with people $(p=0.000)$, the chances of making new friends $(p=0.000)$ than respondents with $<25 \%$ of skin involved.

The feeling of frustration was associated with the progression of vitiligo. Respondents with the disease progression during the last 3 months were more likely to report frustration about their skin condition $(\mathrm{p}=0.05)$.

\section{Discussion}

Our study adds to the positive evidence that vitiligo has a profound impact on QoL, mainly affecting emotional well-being. The gender, age, extent of the skin involvement and progression of vitiligo were found to be associated with some of the impaired emotions and functions that greatly affect overall QoL. In our vitiligo population in Lithuania, education was not associated with patients' QoL.

According to the data of our study, 14 out of 21 areas that influence QoL are affected in $>25 \%$ of patients with vitiligo. Both emotion and functioning-related areas were affected, however, a greater number of patients were influenced by emotion-related areas. The vast majority $(67.4 \%)$ of the patients with vitiligo were concerned about the progression of vitiligo. These findings are in line with previous studies suggesting that emotional factors have a greater impact on patients' QoL than functioning. Of these, concerns about the worsening of the disease play a major role [6]. In general, vitiligo appears to have less influence on activities such as working or studying [7]. Although vitiligo does not cause physical disability, the high financial burden due to the treatment, stigmatization, and social exclusion create multiple emotional problems that can lead to psychiatric disorders. Some of the studies prove that there is a higher prevalence of psychological disorders among vitiligo patients in comparison to healthy ones $[8,9]$. One research concluded that vitiligo is associated with 2.926-fold risk of developing psychiatric disorders [9]. The most studied psychological comorbidities in vitiligo patients are depression and anxiety [10]. The depression was found to be 4.96 times more common among people with vitiligo [11]. Strong evidence of psychiatric comorbidities and impact on emotional wellbeing emphasize the need of efficacious treatment or other management options such as camouflage, which was found to improve the QoL of vitiligo patients [12].

As mentioned before, vitiligo affects both genders equally [1], however, women seem to experience significantly more QoL impairments [9-10]. Moreover, other studies add to the existing evidence that women with vitiligo experience hopelessness, anxiety, community isolation and depression 
more often than healthy ones [8-13]. The difference between genders might be explained by in general higher concerns of appearance in women [15]. In our study, we have found that women are affected more by worry about progression, embarrassment, depressed mood, and annoyance due to vitiligo. Daily life routines concerning appearance such as grooming practices and choice of clothes were found to be more influenced by vitiligo in women.

Literature reports on age and vitiligo affected QoL are conflicting. Even though some sources suggest that younger patients have a poorer QoL [15-16], in our study, older age was found to be associated with impaired domains of QoL. Older people tend to be more frustrated, embarrassed, bothered by vitiligo and worried about other people's opinion. Karelson et al. [7] evaluated QoL and emotional state of vitiligo patients in an Estonian study and found that in the age group of 40-49 years people were most affected. Even showing affection due to vitiligo is harder among older age patients. However, the association of age and QoL is inconsistent among multiple studies. In some studies age was not associated with QoL at all [17-18].

According to our study, the involvement of the body surface area (\%) was found to be associated with impaired QoL. The patients with greater extent of vitiligo patches are usually associated with reduced QoL aspects such as physical and mental health, emotional well-being, and social activities. Multiple studies examine the correlation between the body surface area and DLQI scores. Most of them revealed the strong association between the greater involvement of the body surface area (\%) and reduced QoL. Kiprono et al. [17], Karelson et al. [7], Radtke et al. [16] found that the extent of vitiligo patches and affected body surface area are associated with high DLQI scores. Greater involvement of body surface area has a significant impact on QoL. Thus, more treatment options and psychological help should be considered.

Limitations. The study was performed in a short period of time, and we collected the small study sample. There is also an unequal number of men and women in our sample, therefore it is harder to compare the difference between men and women. Moreover, we have used non-standardized original three-part survey based on DLQI, Skindex-16 and VitiQoL, SA-VES questionnaires. This prevents comparison of results of other studies where standardized questionnaires were used.

\section{Conclusion}

1. We conclude that vitiligo has an influence on patients' QoL in Lithuania, mainly affecting emotion-related areas. In our study QoL is associated with gender, age, and the extent of the skin involvement.
2. Psychological consultation and treatment options should be recommended to patients with vitiligo to improve their QoL.

\section{References}

1. Alikhan A, Felsten LM, Daly M, Petronic-Rosic V. Vitiligo: a comprehensive overview Part I. Introduction, epidemiology, quality of life, diagnosis, differential diagnosis, associations, histopathology, etiology, and work-up. J Am Acad Dermatol. 2011, 65(3), 473-91.

https://doi.org/10.1016/j.jaad.2010.11.061

2. Sehgal VN, Srivastava G. Vitiligo: compendium of clinicoepidemiological features. Indian J Dermatol Venereol Leprol. 2007, 73(3), 149-56.

https://doi.org/10.4103/0378-6323.32708

3. Taïeb A, Picardo M, VETF Members. The definition and assessment of vitiligo: a consensus report of the Vitiligo European Task Force. Pigment Cell Res. 2007, 20(1), 27-35.

https://doi.org/10.1111/j.1600-0749.2006.00355.x

4. Ezzedine K, Sheth V, Rodrigues M, Eleftheriadou V, Harris JE, Hamzavi IH, et al. Vitiligo is not a cosmetic disease. J Am Acad Dermatol. 2015, 73(5), 883-5.

https://doi.org/10.1016/j.jaad.2015.07.039

5. Kostopoulou P, Jouary T, Quintard B, Ezzedine K, Marques $\mathrm{S}$, Boutchnei S, et al. Objective vs. subjective factors in the psychological impact of vitiligo: the experience from a French referral centre. Br J Dermatol. 2009, 161(1), 128-33.

https://doi.org/10.1111/j.1365-2133.2009.09077.x

6. Bae JM, Lee SC, Kim TH, Yeom SD, Shin JH, Lee WJ, et al. Factors Affecting Quality of Life in Patients with Vitiligo: A Nationwide Study. Br J Dermatol. 2018, 178(1), 238-244. https://doi.org/10.1111/bjd.15560

7. Karelson M, Silm H, Kingo K. Quality of Life and Emotional State in Vitiligo in an Estonian Sample: Comparison with Psoriasis and Healthy Controls. Acta Derm Venereol. 2013, 93(4), 446-50.

https://doi.org/10.2340/00015555-1520

8. Hamidizadeh N, Ranjbar S, Ghanizadeh A, Parvizi MM, Jafari P, Handjani F. Evaluating prevalence of depression, anxiety and hopelessness in patients with Vitiligo on an Iranian population. Health Qual life outcomes. 2020, 18:20. https://doi.org/10.1186/s12955-020-1278-7

9. Chen CY, Wang WM, Chung CH, Tsao CH, Chien WC, Hung CT. Increased risk of psychiatric disorders in adult patients with vitiligo: A nationwide, population-based cohort study in Taiwan. J Dermatol. 2020, 47(5), 470-475.

https://doi.org/10.1111/1346-8138.15290

10. Osinubi O, Grainge MJ, Hong L, Ahmed A, Batchelor JM, Grindlay D., et al. The prevalence of psychological comorbidity in people with vitiligo: a systematic review and meta-analysis. Br J Dermatol. 2018, 178(4), 863-878. 
https://doi.org/10.1111/bjd.16049

11. Wang G, Qiu D, Yang H, Liu W. The prevalence and odds of depression in patients with vitiligo: a meta-analysis. J Eur Acad Dermatol Venereol. 2018, 32(8), 1343-1351.

https://doi.org/10.1111/jdv.14739

12. Bassiouny D, Hegazy R, Esmat S, Gawdat HI, Ezzat MA, Tawfik HA, et al. Cosmetic camouflage as an adjuvant to vitiligo therapies: Effect on quality of life. J Cosmet Dermatol. 2021, 20(1), 159-165. https://doi.org/10.1111/jocd.13459

13. Amer AA, Gao XH. Quality of Life in Patients with Vitiligo: An Analysis of the Dermatology Life Quality Index Outcome Over the Past Two Decades. Int J Dermatol. 2016, 55(6), 608-14. https://doi.org/10.1111/ijd.13198

14. Morales- Sanchez MA, Vargas- Salinas M, Peralta-Pedrero ML, Olguin-Garcia MG, Jurado-Santa Cruz F. Impact of Vitiligo on Quality of Life. Actas Dermosifiliogr. 2017, 108(7), 637-642. https://doi.org/10.1016/j.adengl.2017.06.001

15. Hedayat K, Karbakhsh M, Ghiasi M, Goodarzi A, Fakour Y, Akbari Z, et al. Quality of life in patients with vitiligo: a cross-sectional study based on Vitiligo Quality of Life index (VitiQoL). Health Qual Life Outcomes. 2016, 14:86. https://doi.org/10.1186/s12955-016-0490-y

16. Radtke MA, Schafer I, Gajur A, Langenbruch A, Augustin M. Willingness-to-pay and quality of life in patients with vitiligo. Br J Dermatol. 2009, 161(1), 134-9. DOI: 10.1111/j.13652133.2009.09091.x. https://doi.org/10.1111/j.1365-2133.2009.09091.x

17. Kiprono S, Chaula B, Makwaya C, Naafs B, Masenga J. Quality of Life of Patients with Vitiligo Attending the Regional Dermatology Training Center in Northern Tanzania. Int J Dermatol. 2013, 52(2), 191-4. https://doi.org/10.1111/j.1365-4632.2012.05600.x

18. Mishra N, Rastogi MK, Gahalaut P, Agrawal S. Dermatology Specific Quality of Life in Vitiligo Patients and Its Relation with Various Variables: A Hospital Based Cross-sectional Study [Internet]. J Clin Diagn Res. 2014, 8(6), YC01-3.

https://doi.org/10.7860/JCDR/2014/8248.4508

19. Kota RS, Vora RV, Varma JR, Kota SK, Patel TM, Ganjiwale J. Study on Assessment of Quality of Life and Depression in Patients of Vitiligo. Indian Dermatol Online J. 2019, 10(2), 153-7.

\section{SERGANČIŲJŲ BALTME GYVENIMO KOKYBE்S} VERTINIMAS LIETUVOJE

G. Ulianskaitè, A.Timinskaitè, G. Šaltmerè, Matilda Bylaitè-Bučinskienė

Raktažodžiai: DLQI, gyvenimo kokybè, baltmė, VitiQoL.

Santrauka

Baltmė yra lètinė autoimuninė odos liga, pasireiškianti dèl melanocitų netekimo atsirandančiomis depigmentinèmis odos dėmèmis. Nors liga kitų simptomų nesukelia, ji neigiamai veikia pacientų gyvenimo kokybę. Šio tyrimo tikslas buvo įvertinti veiksnius, susijusius su neigiamu poveikiu gyvenimo kokybei, atsižvelgiant i ligos klinikinius požymius, pacientų kasdienį funkcionavimą ir emocinę būklę Lietuvoje. Atliktas pjūvinis anketinis tyrimas, kurị sudare 131 respondentas. Naudotas 41 klausimo originalus 3 daliu klausimynas, parengtas pagal 4 standartizuotus klausimynus. Itraukti 125 respondentai: 94 moterys ir 31 vyras. Vidutinis amžius $35 \pm 12$ metų. Daugiau nei $25 \%$ respondentų teigé, jog baltmé veikia 14 iš 21 vertintų veiksnių, atspindinčių gyvenimo kokybę, įskaitant visus 10 su emocijomis susijusių gyvenimo kokybès rodiklių (100\%) ir 4 iš 11 su kasdieniu funkcionavimu susijusių rodiklių (36,36\%). Apibendrinant, šis tyrimas patvirtino, jog baltmé turi itakos pacientu gyvenimo kokybei, daugiausia emocinei sergančiujų būklei. Gyvenimo kokybè galimai priklauso nuo lyties, amžiaus ir odos pažeidimo ploto. Sergantiesiems baltme turètų būti teikiama psichologinè pagalba.

Adresas susirašinėti: g.ulianskaite@gmail.com

Gauta 2021-08-26 